\title{
A Case of Cavernous Sinus Syndrome with Hypopituitarism Caused by Sphenoid Sinusitis
}

\author{
Midori Tateishi $^{1)}$, Satoshi Seno ${ }^{1)}$ and Takeshi Shimizu ${ }^{2)}$
}

\begin{abstract}
Cavernous sinus syndrome may become fatal if it is misdiagnosed and its treatment is delayed. We report herein on the case of 42-year-old woman with sphenoid sinusitis who developed cavernous sinus syndrome and hypopituitarism. She presented to our hospital with a history of continued headache and swelling of the right eyelid. She was diagnosed as having hypopituitarism based on blood examinations, and computed tomography (CT) imaging revealed right sphenoid sinusitis. Magnetic resonance imaging (MRI) showed local meningitis, right orbital cellulitis and inflammation of the right cavernous sinus.

Endoscopic sinus surgery (ESS) was performed immediately and broad-spectrum antibiotics were administered intravenously before and after the surgery. The patient's condition improved postoperatively, and she was discharged without any complication after 6 days. The pituitary function returned to normal in 1 month without hormonal support.

For the management of cavernous sinus syndrome, enhanced MRI is useful to reveal important intracranial and sinus findings. Although cavernous sinus syndrome is rare, delay in diagnosing may lead to serious complications such as meningitis, brain abscess, visual disturbance and hypopituitarism. Immediate surgical drainage is essential for the treatment of cavernous sinus syndrome caused by sinusitis.
\end{abstract}

Keywords : cavernous sinus syndrome, hypopituitarism, sphenoid sinusitis, endoscopic sinus surgery

\section{References}

1) Gomi $\mathrm{H}$, Gandotra $\mathrm{S}$ and Todd $\mathrm{C}$ : Septic right superior ophthalmic vein thrombosis complicated by left sphenoid sinusitis. Scand J Infect Dis 37: 316-318, 2005.

2) Southwick FS, Richardson EP Jr and Swartz MN : Septic thrombosis of the dural venous sinuses. Medicine (Baltimore) 65: 82-106, 1986.

3) 森野常太郎, 原山幸久, 森脇宏人 : 蝶形骨洞炎による海綿 静脈洞血栓症の 1 例. 耳鼻展望 55: 178-182, 2012.

4) Chen HW, Su CP, Su DH, et al. : Septic cavernous sinus thrombosis: an unusual and fatal disease. J Formos Med Assoc 105: 203-209, 2006.

5) Devèze A, Facon F, Latil G, et al. : Cavernous sinus thrombosis secondary to non-invasive sphenoid aspergillosis. Rhinology 43: 152-155, 2005.

6) Cannon ML, Antonio BL, McCloskey JJ, et al. : Cavernous sinus thrombosis complicating sinusitis. Pediatr Crit Care Med 5: 86-88, 2004.

7) 橋本洋一郎, 伊藤康幸, 光藤 尚, 他：脳静脈血栓症の症
候学. 分子脳血管病 9: 385-391, 2010.

8) Petty RK, Wardlaw J, Kennedy PG, et al. : Panhypopituitarism after cavernous sinus thrombosis. J Neurol Neurosurg Psychiatry 57: 1010-1011, 1994.

9) 竹内万彦, 宮本由起子, 今西義宜, 他 : 視器合併症をきた した副鼻腔炎症例の検討. 日鼻科会誌 46: 319-324, 2007.

10）宮澤哲夫, 飯野ゆき子, 矢部多加夫, 他：鼻性頭蓋内合併 症の 2 症例. 耳鼻展望 38: 197-203, 1995.

11）森野常太郎, 杉本直基, 山本和央, 他 : 硬膜下膿瘍をきた した急性副鼻腔炎の 1 例。耳鼻展望 56: 111-119, 2013.

12）鳥田宗義, 太田将嘉, 臼田里香：慢性副鼻腔炎放置により 沉下垂体前葉機能低下症に至った一例. 日内分泌会誌 77 : 136, 2001.

13）安井康順, 木村哲雄, 竹田宗弘, 他：歯性上顎洞炎に続発 した海綿静脈洞症候群の 1 例. 日口腔外会誌 46: 99-101, 2000.

14) 馬場駿吉 : 視神経炎, 翼口蓋窩, 頭蓋内合併症 (鼻). 耳 鼻咽喉 52: 747-750, 1980.

15) Hoffman $\mathrm{O}$ and Weber RJ : Pathophysiology and treatment of
1) Department of Otorhinolaryngology, Kohka Public Hospital

2) Department of Otorhinolaryngology, Shiga University of Medical Science
Corresponding Author Address : Midori Tateishi

midori66midori66@yahoo.co.jp 
bacterial meningitis. Ther Adv Neurol Disord 2: 1-7, 2009.

16) Harris FS and Rhoton AL : Anatomy of the cavernous sinus. A microsurgical study. J Neurosurg 45: 169-180, 1976.

17) 石坂成康, 萠拔陽子, 法里 高: 視力低下, 全外眼筋麻痺 と沉下垂体機能低下を生じた副鼻腔炎の 1 症例. 日鼻科会
誌 45: 307, 2006 .

18）中嶋秀人, 福本吉人, 蓬莱㻟磨, 他 : 急性化膿性副鼻腔炎 を契機に empty sella 症候群および汎下垂体機能低下症を来 した 1 例. 日内科会誌 82: 584-585, 1993.
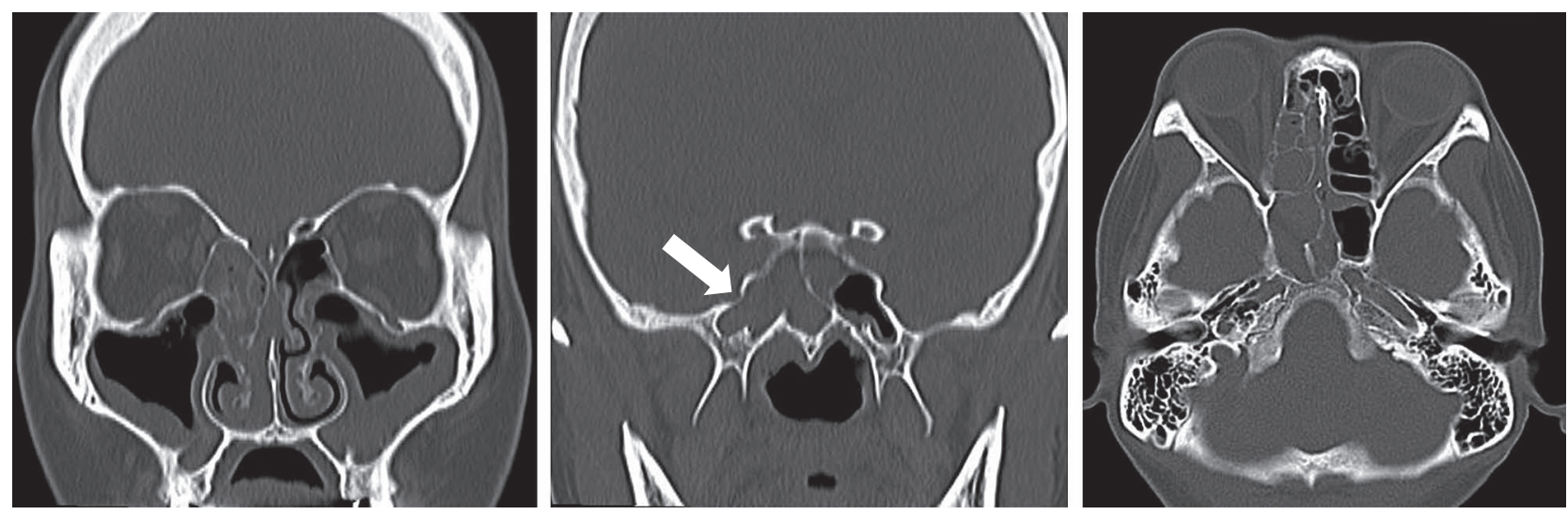

Preoperative computed tomography of the paranasal sinus

Soft tissue density can be observed in the bilateral maxillary sinus, right ethmoid sinuses and right sphenoid sinus, with thinning of the bony wall of the right sphenoid sinus (arrow).

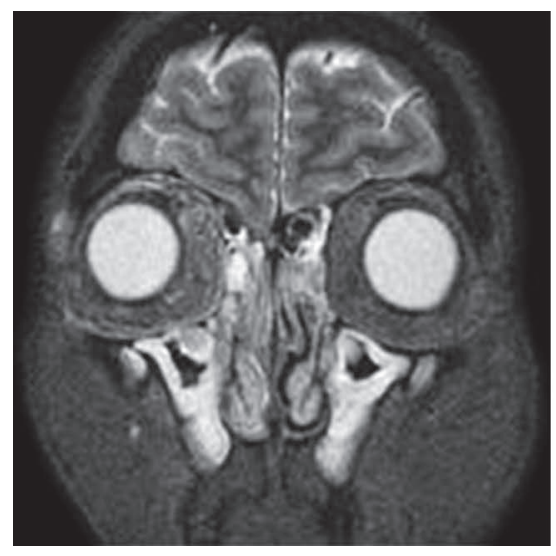

a

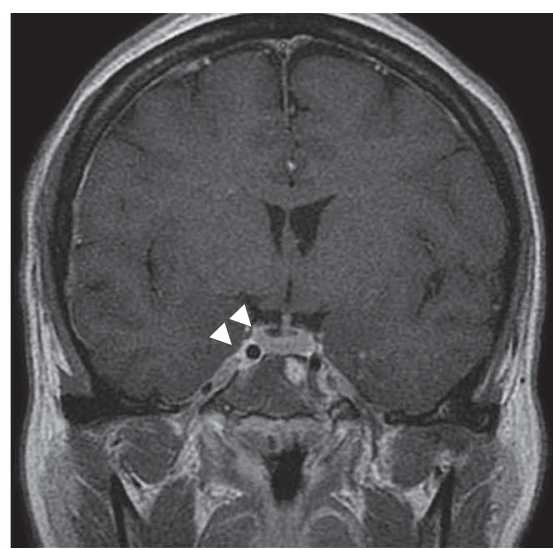

b

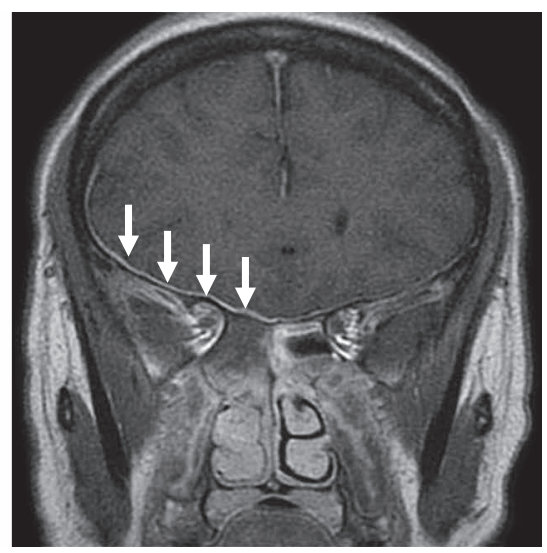

C

Preoperative findings in enhanced magnetic resonance imaging (T2-weighted images)

Thrombosis cannot be detected in the cavernous sinus.

a: Fat tissue in the right orbit demonstrates iso-high intensity.

b: Strong enhancement can be observed in the portion of the right internal carotid artery in the cavernous sinus part (arrowheads).

c: The dura mater in the right hemisphere is enhanced, indicating hypertrophy (arrows). 